\title{
Challenges and Problems of Decentralization in Infrastructure Development to Improve Public Welfare (Case Study at Rokan Hilir District, Indonesia)
}

\author{
Ali Asfar 1, *, Soesilo Zauhar², Siti Rochmah², Hermawan ${ }^{2}$ \\ ${ }^{1}$ Doctoral Program of Public Administration, Brawijaya University, Malang, Indonesia \\ ${ }^{2}$ Faculty of Public Administration Science, University of Brawijaya, Malang, Indonesia
}

Email address:

ali.asfar.ub@gmail.com (A. Asfar)

${ }^{*}$ Corresponding author

\section{To cite this article:}

Ali Asfar, Soesilo Zauhar, Siti Rochmah, Hermawan. Challenges and Problems of Decentralization in Infrastructure Development to Improve Public Welfare (Case Study at Rokan Hilir District, Indonesia). Journal of Public Policy and Administration. Vol. 5, No. 2, 2021, pp. 44-52. doi: $10.11648 /$ j.jppa.20210502.13

Received: April 14, 2021; Accepted: May 5, 2021; Published: May 14, 2021

\begin{abstract}
The purpose of this study is to describe and analyze the challenges and problems of implementing decentralization in infrastructure development. In this case the question is related to central and regional development regulations, the interests between the central government and local governments in infrastructure development and related development budget issues. This study uses a descriptive approach (descriptive research) with qualitative research methods (qualitative research). Research findings show the challenges and problems faced in the decentralization of infrastructure development, among others: First, related to differences in regulations between the central government and local governments, central government regulations that are not in accordance with the wishes and make it difficult for the Regional Government of Rokan Hilir District to carry out regional development. Second, there are differences in the interests of the Government which prioritize the interests of the state as a whole compared to the interests of the people in the regions. Third, Actors who have a dominant role in compiling programs, budgets and implementing infrastructure development in the Rokan Hilir District are the executive and legislative. Other actors such as Business Actors, Religious Leaders/Organizations, Educational Institutions/Providers, and NonGovernmental Organizations are less involved in preparing programs, budgets and implementing infrastructure development.. Fourth, the operating budget to pay temporary staff salaries at the Government Office and routine expenditures for the benefit of the government is bigger than the budget used for development. In addition, there are relatively few financial assistance funds from the Provincial Government to the Rokan Hilir district government, so that it does not support the infrastructure development budget.
\end{abstract}

Keywords: Decentralization, Infrastructure Development, Publik Welfare, Rokan Hilir District

\section{Introduction}

Decentralization policy has become a trend of government management during the last few decades, after previously centralization policies dominated government management in many countries in the world. In Indonesia, the decentralization policy has actually started a long time ago, namely since the issuance of Law no. 1 of 1945 concerning the establishment of the Central Indonesian National Committee. However, the so-called "big bang" decentralization policy in Indonesia has only started since
January 1, 2001, which was marked by the enactment of Law no. 32 of 2004.

Decentralization from a policy and administrative perspective is a form of transfer of planning, decisionmaking, or administrative authority from the central government to its organizations in the field, local administrative units, semi-autonomous organizations, and parastatal organizations, local governments (regional) or nongovernmental organizations [1]. The goal of the state to implement a decentralization policy, among others: First, decentralization is applied in an effort to political education. 
Second, as a political leadership training medium. Third, to maintain political stability. Fourth, to prevent the concentration of power at the center. Fifth, to strengthen public accountability. Sixth, to increase the sensitivity of the elite to the needs of the public [2].

Through decentralization, local governments have a more role in development because they now have the authority and responsibility to carry out community development in their jurisdiction. Because local governments are considered to have better knowledge about the needs and preferences of their citizens, the development process in the decentralization policy model should be more efficient than the centralized policy model in the framework of improving local public welfare.

Decentralization, which sends power and resources from the Central to local governments, comes with several theoretical promises. Decentralization has made some gains in meeting the real needs of local people in terms of service provision. The effectiveness of administrative, fiscal and political decentralization along with clear channels for local accountability and transparency are necessary for improved and quality service provision [3]. Effectively decentralizing infrastructure requires the careful development of different (asymmetric) approaches for different sizes and types of subnational government structures. [4]

International experience shows that decentralization has a positive impact on development performance. A review of the literature indicates that there are many significant contributions from decentralization in various sectors, for example in the prevention and eradication of corruption [5], poverty reduction [6], improving service quality [7], strengthening accountability [8], conflict resolution [9] or community empowerment [10].

The decentralization policy has empowered subnational governments to be more proactive in transforming their own regions, but the effect of these initiatives on regional development remains unclear and varies across regions due to differences in capacity, both technical and administrative. In fact, the early period of Indonesia's decentralization policy has provided the conditions for local governments to be inward looking. They competed among themselves to maximize their local revenues without paying attention to the adverse effects on their neighbouring regions. The central government made numerous institutional adjustments so that the decentralization frameworks could better adapt to the dynamics of social and political reality. As a result, more positive outcomes began to emerge [11].

On the other hand, decentralization can also cause budgetary problems, increase macroeconomic instability and regional disparities, give rise to regional egoism and clientelism, or swell the bureaucratic structure. Thus, decentralization has two faces, positive and negative, which in the language of Alex Brillantes Jr. said to be two edged of sword [12].

Two faces of decentralization were also expressed by Dillinger, that in terms of benefits, decentralization can more precisely increase the efficiency and responsiveness of the government through the fulfillment of public services that are more in line with people's preferences. In addition, decentralization can generate a spirit of competition and innovation among local governments to achieve higher community satisfaction. But on the other hand, the quality of public services is often the victim because the transfer of authority is often misinterpreted or misused by local elites who are relatively inadequate to the required competency standards [13].

Development in the context of decentralization and regional autonomy can be used as basic capital in carrying out community development. Community development is actually endogenous development by utilizing the right potential of human and natural resources, institutions and technology. In Indonesia, the concept of decentralization which should be implemented is responsible to the people, but its realization has not received serious attention, so that it has not been able to improve welfare. Related to the issue of national development integration, both from the aspects of planning and development realization. This occurs as a consequence of the direct regional head election mechanism. Regional heads who have their own development programs make it difficult for the central government to integrate the National Medium Term Development Plan with the Regional Medium Term Development Plan. Especially if this is viewed from a political aspect, namely the background of the political parties of each regional head. This has resulted in many development programs that are difficult for the government to harmonize due to differences in direction and policy assumptions used by each party.

Regional development is an integral part of national development. In other words, on the one hand the principle of decentralization creates regional autonomy, including in the context of development (decentralized development). On the other hand, it is necessary to achieve the same vision and mission of the regional development plan with the national development plan. Furthermore, from the perspective of performance management, the cascading principle is known that it must be possible to identify the contribution of performance/achievement of development targets to the achievement of national development targets. According [14], based on Stufentheorie, regional development planning arrangements should not conflict with national development planning arrangements. In order to avoid conflicts, it is necessary to have harmony and harmony in development based on the principles of decentralization.

The challenge that arises is how the Regional Government carries out infrastructure development so that regional development goals are in accordance with the concept of central government development based on the principle of decentralization, of course, in this case there is a need for similar regulations, the same interests between the central government and local governments in infrastructure development. Based on this, this research aims more broadly to describe and analyze the challenges and problems of implementing decentralization in 
infrastructure development. In this case the question is related to central and regional development regulations, the interests between the central government and local governments in infrastructure development and related to the development budget issues.

\section{Literature Review}

\subsection{Decentralization}

Decentralization refers to the global trend in shifting responsibilities of the central government to local or local governments. The definitions and interpretations of decentralization vary widely between countries, among scientists, and among government practitioners. The term decentralization has different meanings for different people, and approaches to decentralization vary widely from country to country. The term decentralization means different things to different people, and the approach to decentralization has varied widely between countries [15].

Decentralization, in general, is a structural change of government through the transfer of power and authority from the national to the subnational levels. The transfer of authority to government at the regional level has fundamentally changed the status, power, and behavior of the government [16]. Decentralization has the general goal of increasing the efficiency and responsiveness of government [17], accelerating growth, and spreading development and resource use, especially for economically underdeveloped areas [18].

The Decentralization is a concept that describes the phenomenon of the transfer of authority, resources, and responsibility between governance institutions (market, government, and civil society). Typically, decentralization is implemented through deconcentration, devolution and delegation [18]. However, today, decentralization can be implemented through the format of political decentralization, administrative decentralization, fiscal decentralization, and economic decentralization [19].

The Decentralization is the transfer of planning, decisionmaking and/or administrative authority from the central government to central organizations in the regions, local administrative units, semi-autonomous and parastatal organizations (companies), local governments or nongovernment organizations. The difference in the concept of decentralization is determined primarily based on the level of authority for planning, deciding, and managing the powers transferred by the central government and the amount of autonomy received to carry out these tasks [19].

\subsection{Decentralization and Regional Development}

Development Administration deals with the administrative process of a development program, with the methods used by large organizations, especially the government to carry out policies and activities that have been planned in order to achieve their development goals. Second, the meaning of the term development administration is related to its implications, not its direct meaning. This includes increased administrative capacity. Clearly, if a development program is successfully implemented, it can automatically lead to changes in the political community, including changes in the capacity of society in the administrative field [20].

Since reforms began in the late 1990s, Indonesia has pursued an ambitious policy of decentralization. One of the goals is to foster regional development from below by giving greater flexibility to local governments in determining programs that are more aspirational for the interests of the community and regional and regional development goals [11]. The implementation of decentralization also shows the increasing competition between cities, especially in the economic development that occurs in China [21]. Furthermore, according [22] that competition between local jurisdictions to enhance local economic development, which is one of the main goals of decentralization, can have unintended consequences.

Decentralization promises more efficient development and encourages a bottom-up approach to development. In addition, encouraging competition between local governments to spur regional economic growth and improve public services at the regional level. However, it was found that decentralization had caused some downsides. Several studies have shown that decentralization has had detrimental impacts, such as decreasing the quality of public services [22], increasing disparities between regions [23], and resulting in more corrupt governments [24]. Therefore, this problem becomes a big challenge in implementing a decentralized system in developing countries, most of which have weak institutional capacities.

Effective implementation of decentralization in regional planning and development facilitates the adaptation of development programs to the needs and needs of local communities, as it allows community participation from various administrative units in the process of formulating and implementing regional development policies and provides the necessary support to mobilize energy and mobilize resources. The chances for the success of this policy are to achieve the goal in a balanced manner which guarantees justice and equality for all citizens and in all areas of the country. This success has contributed to achieving regional balance and reducing economic, social, and urban disparities between regions, given that the allocation and monitoring of investment in the community is closely related to the distribution of decision-making power.

Therefore, an understanding of how the relationship between the central government and local governments in the Unitary State of the Republic of Indonesia should be in accordance with democratic values and reflects the harmony between the central government and local governments. In a unitary state, regardless of the extent of regional autonomy or government affairs transferred to the regions, the authority of the regional government to regulate and administer remains within the boundaries of the national policy corridors set by the Central Government. Regional government in formulating regional policies must not conflict with national 
policies. This is intended to create harmony between the Central Government and regional governments.

\section{Methodology}

Based on the objectives to be achieved in research, namely, to be able to describe, explain or describe the results of the research in full and in depth, the type of research used is qualitative (qualitative research). Data collection techniques in this study include interviews, observations/observations, documentation and literature study. The informants in the study included the competent authorities consisting of the Regional House of Representatives, the Rokan Hilir District Government, Community Elements and Figures who were determined on an ongoing basis using purposive sampling technique.

Data analysis techniques in research used techniques developed by [25], namely Grouping the data according to key constructs, identifying bases for interpretation, Developing generalizations from the data, Testing Alternative interpretations and Forming and/or refining generalizable theory from case study.

\section{Results and Discussion}

\subsection{Central Government and Local Government Regulations in Infrastructure Development}

The implementation of decentralization during the reform era essentially brought benefits for local governments to take a more tangible role in the midst of the people they protect. However, in principle it cannot be ruled out that there are empirical obstacles that have arisen in the implementation of decentralization in Indonesia. This is related to the issue of national development integration both from the aspects of planning and realization of development. This occurs as a consequence of the direct regional head election mechanism. Regional heads who have their own development programs make it difficult for the central government to integrate the National Medium Term Development Plan which is a National program with the Regional Medium Term Development Plan which is the development program for Regional Heads. The different conditions of development plans will result in differences in regulations between the central government and local governments.

Regional development policies are based on the principle of decentralization to expand participation in decisionmaking. The decentralized development approach is based on dividing government into vertical levels on a logical basis, taking into spatial data, economic, social, and administrative data and then dividing responsibilities and powers between these levels based on economic and political factors, taking into account how to carry out those responsibilities. and the ability of government to carry out its functions the decentralized development approach aims to broaden the basis for decision making by dividing responsibilities into levels and categories depending on the scope of their influence, thereby facilitating local decisions that affect the daily life of citizens by local governments directly, so that accelerate regional development.

The importance of infrastructure development is not only to open up territorial isolation, increase accessibility in the economic, socio-cultural fields but also to support the smooth running of citizen activities and also to facilitate the implementation of government tasks and public or public services by public administrators to the community, because public administrators are public services. as the duty and function of the state apparatus as a public servant. To carry out fast, precise, and good infrastructure development, which can be accounted for and according to the wishes of the community, clear regulations or rules are needed, then new development can be carried out if there is good and rational cooperation between providers and implementers including paying attention to aspirations or desires Public.

The implementation of decentralization is not as simple as it is understood in concepts and theories. The issue of decentralization is very complex and complex. There are many social, political, economic, and cultural dimensions that influence the success of implementing decentralization in a country. Regarding the implementation of decentralization in areas outside Java, showing results that are increasingly democratic, regional governments have been able to independently determine what their regions need. However, there are still differences in policies between district/city, provincial and central governments.

The findings of the study show that the lack of infrastructure in the regions is still related, this is because there are still differences in development regulations between the central government and the regional governments. The Central Government is committed to accelerating infrastructure development throughout the country, this is stated in regulations in the form of Presidential Regulation number 3 of 2016 and Presidential Instruction number 1 of 2016 concerning the Acceleration of Implementation of National Strategic Projects. Accelerated development includes the Electricity Infrastructure Development Program, the Economic Equalization Program, the Border Area Development Program, the Exit Toll Access Road Development Program, the National Tourism Strategic Area Development Program, the Waste Processing Installation Program for Electrical Energy, the Smelter Development Program, National Food Supply Improvement Program (Food Estate), Superhub Development Program, and Regional Development Acceleration Program.

The Rokan Hilir District Government is committed to accelerating infrastructure development, this is marked by the issuance of regulations in the form of Riau Province Regional Regulation Number 2 of 2006 concerning Increasing the Multi-Year Activity Budget Fund, with the aim of including increasing infrastructure development, namely strategic scale development to realize the Strategic Plan and poverty alleviation programs, eradication of ignorance and improvement of infrastructure development that have been announced by the Regional Government. 
The central government in making regulations should be studied in depth and adjusted to the conditions of each region without neglecting local wisdom and listening to the aspirations and input of the community, so that people can get good services so that prosperity can be realized. According to [26], one of the reasons for the importance of structuring regulations in Indonesia is: 1) Hyper-regulation. 2) Conflicting. 3) Overlapping. 4) Multi Interpretation 5) Inconsistency. 6) Not effective. 7) Unnecesarry Burden. 8) High-Cost Economy.

Based on these empirical facts, it is necessary to understand how the relationship of authority between the central government and local governments in the Unitary State of the Republic of Indonesia should be in accordance with democratic values and reflect justice and harmony between the central government and local governments. The regional government has the authority to regulate and manage government affairs by itself according to the principles of autonomy and assistance tasks. Local governments need to carry out communication, consultation, and coordination in regional development. In government administration, communication, consultation, and discussion are intended to harmonize and unify the activities carried out by leading officials or groups of implementing officials. A coordinated act of implementation means that the activities of groups of officials become harmonious, in achieving common goals. The coordination concept also applies to regional development coordination. Regional development coordination is carried out both at the development planning stage and at the development implementation stage.

The decentralization process should emphasize the importance of regional planning over sectoral planning. It is the only way to transform sectoral objectives into a common framework that serves as a regional development strategy that enables people's participation and ensures interdependence, harmony and integration between relevant agencies and institutions by preparing and implementing regional development plans. Therefore, official planning agencies at the regional level must have authority with high efficiency in order to carry out their roles properly [27]. The principles of decentralization, namely 'buttom-up' planning, full participation of the whole community, and a more balanced distribution of resources between the central government and regional governments as well as the development plans of local governments are an integral part of the national development plan.

\subsection{Central and Local Government Interests}

Central Government and Local Government Relations. The regional autonomy that has been implemented so far has only been understood as a transfer of the obligations of the central government to local governments for the community. Whereas the important substance of regional autonomy is the delegation of authority from the center to the regions politically and economically so that development and economic growth take place fairly and evenly in the regions. The concept of decentralization in Law Number 23 of 2014 is the transfer of Government Affairs by the Central Government to the autonomous region. The handover of these functions is intended to bring efficiency and effectiveness of regional government administration which needs to be improved by paying more attention to aspects of the relationship between the Central Government and regions and between regions, the potential and diversity of regions, as well as the opportunities and challenges of global competition in the unity of the state administration system. In addition, the implementation of regional government is directed at accelerating the realization of public welfare. through improving services, empowerment, and community participation, as well as increasing regional competitiveness by taking into account the principles of democracy, equity, justice and the uniqueness of a region in the system of the Unitary State of the Republic of Indonesia

Analysis of the interests of each district and city, province and central government in infrastructure development can be seen in their respective efforts to optimize regional potential and allocate regional resources owned. In the context of development decentralization there are always potential agency problems where delegated recipients of authority (local government/agent) act inconsistent with the interests of the giver of authority (Central Government, principal).

The central government has many interests with the regions because the regions have abundant natural resources, then for the sake of the integrity of the Unitary State of the Republic of Indonesia, the Central Government makes national strategic activities carried out in the regions. The activities and interests of the regional center should be in harmony with regional interests and should not be in conflict for the sake of the survival of the nation and state.

The research findings show that based on the viewpoint of the Rokan Hilir local government, the central government prioritizes the interests of the state as a whole rather than the interests of the local community. Decentralization has not been fully implemented, there is no central government policy to provide development results, especially infrastructure for Rokan Hilir District. Empirically, Rokan Hilir District is the largest contributor of crude oil to the state (30\%), especially from the Rokan Hilir Block, but infrastructure development is not as high and as fast as other cities outside Rokan Hilir District. The development of road infrastructure that connects regencies/cities and between provinces is very much needed for the smooth flow of goods and people. The development of this road access is the responsibility of the central government, especially interdistrict and proventions to increase and equitable development and maintain harmony between central and regional interests.

Decentralization of development planning cannot take place for several reasons. First, there are differences in objectives between national development planning and regional development planning. The difference occurs not at the macro level, namely in order to achieve a just and prosperous society, both nationally and in each region, but at a more micro level. The aim of national development 
planning is to solve problems that often occur at the national scale. Analogy with that, the purpose of regional development planning is to solve problems that occur at a regional scale. Of course, national problems are not the same as regional problems.

Based on the principle of decentralization, the Central Government will delegate governmental authority to the Autonomous Regional Government within the framework of the Unitary State of the Republic of Indonesia. This is intended so that the smooth running of governance and development can be more secure, in addition to increasing community participation in governance by taking into account the potential and diversity of regions. In a unitary state with a decentralized system, the position of the Regional Government is lower than the Central Government (absence of subsidiary bodies).

The law requires that the Regional Medium-Term Development Plan must be in accordance with the National Medium-Term Development Plan. Ideally, regional interests in the central government are set forth in activity program proposals to Ministries/Institutions through the National Development Plan Consultation mechanism, while the regional government and its subordinates are set forth in proposals through the Village, District, Regency and Provincial Development Plan Deliberation mechanisms. The research findings show that it turns out that many of the program proposal mechanisms are not realized, the classic reason that is often faced is limited funds/budgets.

Based on the principle of decentralization, the interests of the Central and Regional Governments in infrastructure development must ensure that the interests of the local community are accommodated and that the interests of the regional and central governments are shared will spur the realization of local public welfare.

\subsection{Interests of Central and Regional Actors}

The implementation of decentralization places local governments as important actors in the development process and regional management. There is high optimism for the implementation of decentralization in creating a development process that is more oriented towards local communities. Actors or actors in the policy process are divided into two groups, namely the official actors and the informal actors. Official actors are agents of the government (bureaucracy), executive, legislative and judiciary. Meanwhile, those included in the informal cast group include interest groups, political parties, and individual citizens [28-31].

Actors who have a role in the process of determining development policies are the legislative and the executive. Legislative in this case the Regional House of Representatives has four main functions, namely making regional regulations, compiling financial budgets, supervising local governments, and electing regional officials. In carrying out these four functions, the Regional House of Representatives is required to always consider the aspirations and interests of the people. The regional autonomy policy has made the legislature have an equal role with the executive.
The bargaining stage can occur in three forms, namely negotiation, give and take, and compromise. Bargaining is rooted in the presence of two or more actors or groups of actors who each have certain powers and positions but can make adjustments that can be built into policy discussions. Negotiations are the initial stage for forming opinions from actors. In the end there will be a compromise process where each actor makes adjustments to the other actor's concepts or ideas so that a policy is approved [28].

The interaction mechanism between actors in infrastructure development brings together the interests of each actor, taking place throughout the development formulation and planning process. This intensive interaction mechanism makes it easier for opportunities to mutually accommodate the interests of each actor. The factors that are very important in the formulation of a policy are what issues deserve to be considered a problem, or how the issue is formulated, how well the core of a problem is defined, what values and ethics accompany its goals, objectives, and solutions [32].

Based on the research results, that infrastructure development in Rokan Hilir District is strongly influenced by Executive Actors and Political Actors (Legislative), this should not have happened. When referring to several opinions about what affects development, all actors should be compatible with each other to achieve the desired development together. According to [33], there are 7 actors who play a role in development, namely executives, politicians, business actors, leaders/religious organizations, educational institutions/administrators, non-governmental organizations.

Development will be carried out well if it has become a commitment of all components of society, meaning that all members of the community participate and work hand in hand, fill each other in a race for creativity, innovation in development and not just being spectators. The several elite groups that have a role in development, namely Political Elite, Administrative Elite, Academic Elite, Captains of Industries, Military Elite, Informed Observers [34]

The role played by the political elite is recognized to be able to mobilize community participation because it holds a prominent position in society, especially the smallest unit in development. The Regional Revenue and Expenditure Budget often becomes an arena for political battles, starting with political elites at the village and district levels (executive and legislative). As a result, many of the activities proposed in the Regional Revenue and Expenditure Budget are "entrusted" activities from certain parties who it is definitely not the result of the absorption of public participation, even though the budget is relatively small.

The research findings show that political intervention is no longer an open secret. On the pretext of being in the public interest, various parties often with their powers force an activity to be included in The Regional Revenue and Expenditure Budget. Sometimes this results in the loss of community proposals based on the Development Plan Deliberation, which does not only occur in the process of 
proposing The Regional Revenue and Expenditure Budget Planning, but also at the time the discussion is carried out, if studied further, not all of these activities are important and describe the needs of the community in the sense that the benefits are not widely felt by the community.

Empirical facts show that the Rokan Hilir District Government has tried to include and synergize all components, elements, and development elites, because the Rokan Hilir District Government believes that not all development problems can be resolved by the Executive and Legislative only, it must be consulted by elements, components, and elites. Other developments, including the private sector or businessmen, involve other components, it is hoped that they will feel responsible and have a sense of belonging to development and become their thoughts on how development can be carried out as desired by the community. The harmony of the interests of the determining actors, namely between the Executive and the Legislature in formulating policies for infrastructure development, as well as the existence of sufficient regulations to support the realization of the goals of infrastructure development for public welfare.

\subsection{Central and Regional Infrastructure Development Budgets}

One of the main components of the decentralization concept is fiscal decentralization. If local governments implement their functions effectively and are given the freedom to make decisions about the provision of services in the public sector, then they must be supported by adequate financial sources, both originating from Regional Original Income including taxes, tax and non-tax revenue sharing, loans. Regions, as well as Special and General Subsidies from the Central Government. Fiscal decentralization initiatives are based on the objectives of fiscal policy, namely efficiency of resource allocation, redistribution of income, and macroeconomic management.

According to the thinking of [35], it is explained that the relationship between central and regional governments in the dimensions of the state power system is still ambiguous. In Held's thought, the state is positioned as an arena for social struggle which is manifested in the form of the organization, administration and policies that are produced. Meanwhile, according to [36] that the characteristics of the state often show the regional struggle for more appropriate autonomy is an inevitable fact. large to finance comprehensive and sustainable infrastructure development. The irony is that the government's ability to provide funds to provide infrastructure is far from sufficient.

At the local government level, the budget allocation for infrastructure continues to increase, however the findings of the Regional Autonomy Implementation Monitoring study show that this increase in budget was not followed by an increase in the quality of infrastructure. Corruption is seen as a reason for the problem of the inconsistency between the increase in the budget and the quality of infrastructure. The function of allocating public resources and the distributive function of the budget must be maximized, namely the process of allocating and distributing sources of public funds in an economical, efficient, effective, fair, and equitable manner [37]. According to [38], that regional autonomy is generally followed by fiscal policy as an instrument that supports local governments in public services through the transfer of funds to the regions.

Government budgets and expenditures should be used for programs that are in direct contact with the community and can act as a driving force for the economy, equitable development and improving public welfare. For justice, welfare, and prosperity of the wider community, it is necessary to have a budget harmony between the Government and the Regional Government, the budget does not have to accumulate in the Central Government, but a large budget is needed to be given to local governments to build infrastructure and others. Likewise in the preparation of the Regional Opinion and Expenditure Budget, the infrastructure development budget (direct costs) must be greater than the operational budget (indirect costs).

Research findings and facts in the field, it was found that in the Rokan Hilir District from 2012 to 2019 the operational budget was greater than the development budget, the implication is that it is almost impossible to carry out physical development (infrastructure). The financial relationship between the central and local governments is more likely to be influenced by political factors. Since 2001, every regional government has basically had good financial resources, among others, First, Transfer Funds from the central government in the form of General Subsidies or General Allocation Funds and Special Subsidies or Special Allocation Funds; Second, Regional Original Income (PAD) which can be obtained from the income of Regional Taxes, Levies, and Profits from Regional Owned Enterprises. Therefore, each regional head has the convenience of implementing development programs in his region. Moreover, the enthusiasm for implementing the development program is to gain sympathy and praise from the community and other parties. The problem is, most of the regional transfer funds are allocated for personnel expenditure or paying employee salaries. As a result, funds for the capital budget, including funds for infrastructure development, road maintenance, are small and even lack the budget.

Many developing countries have implemented fiscal decentralization policies due to escape from the traps (traps) of government inefficiency, macroeconomic instability and insufficient economic growth that have caused these countries to fall into a trap [39]. The regional autonomy and generally followed by fiscal policy as an instrument that supports local governments in public services through the transfer of funds to the regions. Furthermore, fiscal decentralization must be taken seriously by local governments to implement development, support economic growth both at the local (regional) and national levels. It should be noted that fiscal decentralization in the era of regional autonomy in Indonesia, namely fiscal decentralization in the expenditure side is financed, especially regional transfer funds. Thus, fiscal decentralization as the essence of fiscal management autonomy must be oriented 
towards the freedom to spend funds according to the priorities and needs of each regional government. [38].

\section{Conclusion and Policy Recommendations}

In principle, the concept of decentralization can be designed to encourage future development and improve public welfare, reduce regional disparities, and produce equitable development in a region. The development authority given by the central government through various government affairs ranging from education, health, to tourism can only be carried out incrementally, where various challenges and problems remain. The challenges and problems faced include: First, related to differences in regulations between the central government and local governments, central government regulations that are not in accordance with the wishes and make it difficult for the Rokan Hilir District Government to carry out development. Second, there are differences in the interests of the Government which prioritize the interests of the state as a whole compared to the interests of the people in the regions. Third, the ineffective communication, consultation and good discussion between the executive and the legislature. Executive and legislative actors are still dominant in formulating programs, budgets, and implementation of development so that there is no harmony with other actors, including the community. Fourth, the limited budget, which is more dominant in the operational budget compared to the development budget, is due to the lack of central financial assistance funds provided to the regions.

Decentralization of infrastructure development can be carried out well if between the center and the regions to intensify communication, consultation, and discussion, treat the regions as working partners, reinforce obligations or responsibilities between the central and regional governments, carry out formal cooperation which is specific to achieve goals or solve certain problems. The opportunity of managing (management) infrastructure development with good public administration as an effort to improve public welfare. through a systematic approach covering planning, budgeting, implementing, controlling, and evaluating in an integrated manner in infrastructure development activities. This effort involves all development actors, not only the executive and legislative branches at various levels, as well as the community including the business community/private sector by mobilizing natural resources and human resources in order to achieve prosperity in justice or improve public welfare.

\section{References}

[1] Cheema, G. S. dan Rondinelli, D. A., (1983). Decentralization and Development: Policy Implementation in Developing Countries. Beverly Hills; London; New Delhi: Sage Publications.
[2] Nurcholis, Hanif. (2007). Teori dan Praktik Pemerintahan Dan Otonomi Daerah. Jakarta, Grasindo.

[3] Dick-Sagoe, C. (2020). Decentralization for improving the provision of public services in developing countries: A critical review. Cogent Economics \& Finance. 8: 1, 1804036, DOI: 10.1080/23322039.2020.1804036.

[4] Bahl, R and Bird, R. (2013). Decentralization and Infrastructure in Developing Countries: Reconciling Principles and Practice. IMFG Paper s on Municipal Finance and Gover nance. No. 16, 2013. Andrew Young School of Policy Studies, Georgia State University, and Institute on Municipal Finance and Governance.

[5] Arikan GG., (2004), "Fiscal decentralization: A remedy for corruption?" dalam International Tax and Public Finance 11 (2): 175-195.

[6] Braathen, Einar, 2008, Decentralisation and Poverty Reduction, A Review of the Linkages in Tanzania and the International Literature, Norad Report 22b/2008 Discussion, Norwegian Agency for Development Cooperation. Tersedia online

http://www.norad.no/items/14184/38/2084279701/Decentralis ation\%20and\%20Poverty\%20Reduction.pdf.

[7] World Bank (2005) "Decentralization and Governance: Does Decentralization Improve Public Service Delivery?" in Prem Notes No. 55. http://www1.worldbank org/prem/PREMNotes/premnote55. Pdf.

[8] World Bank, 2001 Decentralization and governance: Does decentralization improve public service delivery? Working Paper Series.

[9] Sasaoka, Yuichi, 2007, Decentralization and Conflict, The $889^{\text {th }}$ Wilton Park Conference, Japan International Cooperation Agency.

[10] Brinkerhoff, Derick W and Omar Azfar. 2006, Decentralization and Community Empowerment: Does community empowerment deepen democracy and improve service delivery? U.S. Agency for International Development Office of Democracy and Governance.

[11] Talitha, Tessa., Tommy, F \& Delik, H. (2019). Welcoming two decades of decentralization in Indonesia: a regional development perspective. Territory, Politics, Governance https://doi.org/10.1080/21622671.2019.1601595

[12] Brilantes Jr., Alex, 2004, Decentralization Imperatives, Lessons from Some Asian Countries, Journal of International Cooperation Studies, Vo. 12 No. 1, August.

[13] Dillinger, William, 1994, Decentralization and Its Implications for Urban Service Delivery. Urban Management Program Discussion Paper 16, Washington, DC: World Bank.

[14] Purwadi, Ari. (2013). Harmonisasi Pengaturan Perencanaan Pembangunan antara Pemerintah Pusat dan Daerah Era Otonomi Daerah [online] Available at: ejournal. uwks. ac. Id/myfile/201308321915161512/5.

[15] Devas, N. (1997). Indonesia: What do we mean by decentralization? Public Administration and Development, 17 (3), 351-367.

[16] Faguet, J.-P. (2014). Decentralization and governance. World Development, 53, 2-13. doi: 10.1016/j.worlddev. 2013.01.002. 
[17] Bardhan, P. (2002). Decentralization of governance and development. The Journal of Economic Perspectives, 16 (4), $185-205$.

[18] Rondinelli, D. A. (1981). Government decentralization in comparative perspective: Theory and practice in developing countries. International Review for Administrative Sciences.

[19] Cheema, G. S, and Rondinelli, Dennis A., (eds.), 2008. Decentralizing Governance: Emerging Concepts and Practices. Washington, D. C., Brookings Institution Press.

[20] Riggs, Fred W. (ed.). 1994. Fronties of Development Administration. Durham, North Carolina: Duke University.

[21] Shen, J. (2004). Urban Competitiveness and urban governance in the Globalizing world. Asian Geographer, 23 (1-2), 19-36. doi: 10.1080/10225706.2004.9684110.

[22] Prud' Homme, R. (1995). The dangers of decentralization. The World Bank Research Observer, 10 (2), 201-220.

[23] Rodriguez-Pose, A., \& Ezcurra, R. (2010). Does decentralization matter for regional disparities? A CrossCountry Analysis. Journal of Economic Geography, 10 (5), 619-644. doi: 10.1093/jeg/lbp049.

[24] Hadiz, V. R. (2004). Decentralization and Democracy in Indonesia: A Critique of Neo-Institutionalist Perspectives. Development and Change, 35 (4), 697-718.

[25] McNabb, David E. (2002), Research Method in Public Administration and Nonprofit Management, Quantitative and Qualitative Approaches. ME.

[26] Arfan, F. M. (2017). Penataan Regulasi Dalam Mendukung Pembangunan Ekonomi Nasional (Regulatory Reform to Support National Economic Development), Jurnal Rechtsvinding Media Pembinaan Hukum Nasional, 6.(3), 349367.

[27] Pepinsky, T. B., \& Wihardja, M. M. (2011). Decentralization and economic performance in Indonesia. Journal of East Asian Studies, 11 (3), 337-371.

[28] Anderson, James E, (1979). Public Policy Making, Thirds Edition, Holt, Rinehart and Winston, New York Prees.

[29] Lindblom, Charles E. (1980). The Policy-making Process. UK: Prentice Hall.

[30] Lester, James P., and Stewart, J. (2000). Public Policy: An Evolutionary Approach. California: Wadsworth Thomson Learning.

[31] Winarno, Budi. (2008). Kebijakan Publik: Teori dan Proses. Yogyakarta MedPres.

[32] Madani, Muhlis. (2011). Dimensi Interaksi Aktor Dalam Proses Perumusan Kebijakan Publik, Yogyakarta: Graha Ilmu.

[33] Wahab, A. S. (2012). Analisis Kebijaksanaan dari Formulasi ke Implementasi Kebijaksanaan Negara. Jakarta: Bumi Aksara.

[34] Siagian S, P. (2016). Administrasi Pembangunan. Gunung Agung. Jakarta.

[35] Held, David, (1989). Political Theory and The Modern State: Essays on State, Power, and Democracy, Stanford University Press, California, USA.

[36] Burns, D. R. Humbleton dan P. Hoggell, (1994). The Politics of Decentralization: Revitalising Local Democracy, McMillan, Basingstoke.

[37] Mardiasmo. (2002). Akuntansi Sektor Publik. Yogyakarta. Penerbit Andi.

[38] Beier dan Ferrazzi (1998 Beier dan Ferrazzi, 1998, Fiscal Decentralization in Indonesia: A Comment on Smoked Lewis, World Development Report, 26 (12), 2201-2211.

[39] Robert Ebel, 2000, The Economic of Fiscal Decentralization, The World Bank (Paper). 